\title{
PENGARUH PENGGANTIAN JAGUNG DENGAN SORGUM Cv. KAWALI DALAM RANSUM PELLET TERHADAP PERFORMANS KELINCI LOKAL
}

\author{
Agung R. P. Rumondor, B. Tulung, A. Rumambi*, C.A. Rahasia \\ Fakultas Peternakan, Universitas Sam Ratulangi, Manado 95115
}

\begin{abstract}
ABSTRAK
Tujuan penelitian ini dilaksanakan untuk mengetahui pengaruh penggantian jagung dengan sorgum dalam ransum ternak kelinci terhadap konsumsi ransum, pertambahan bobot badan, dan konversi ransum. Lama penelitian selama 28 hari menggunakan 20 ekor kelinci lokal. Rancangan statistik yang digunakan dalam penelitian ini adalah Rancangan Acak Lengkap, dengan 4 (empat) perlakuan ransum dan 5 (lima) ulangan. Keempat ransum percobaan, yaitu R0: $45 \%$ jagung+0\% sorgum, R1: $30 \%$ jagung+ $15 \%$ sorgum, R2 $15 \%$ jagung+30\% sorgum, R3 $0 \%$ jagung $+45 \%$ sorgum. Variabel diukur, yaitu: konsumsi ransum, pertambahan bobot badan dan konversi ransum. Hasil penelitian menunjukkan bahwa rataan konsumsi ransum, pertambahan bobot badan, dan konsumsi ransum, secara berturut-turut, adalah: 28,27-30,59 g/ekor'hari, 15,76-21,55 g/ekor/hari, dan 1,42-1,80 g/ekor/hari. Berdasarkan analisis keragaman perlakuan ransum menunjukkan hasil yang berpengaruh tidak nyata $(\mathrm{P}>0,05)$ terhadap konsumsi, akan tetapi berpengaruh sangat nyata $(\mathrm{P}<0,01)$ terhadap pertambahan bobot badan dan konversi ransum. Uji beda nyata terkecil (BNT) menunjukkan semua ransum perlakuan yang menggunakan sorgum (R1, $\mathrm{R} 2$, dan R3) memberi hasil pertambahan bobot badan yang berbeda sangat nyata $(\mathrm{P}<0,01)$ lebih tinggi dari R0. Sedangkan, pada konversi ransum, perlakuan R1, R2, dan R3 memberi hasil yang berbeda sangat
\end{abstract}

*Korespondensi (corresponding Author) Email: agnitjerumambi@gmail.com nyata $(\mathrm{P}<0,01)$ lebih rendah dari $\mathrm{R} 0$.

Berdasarkan hasil pembahasan dapat disimpulkan bahwa penggantian jagung dengan sorgum pada level $45 \%$ dalam ransum, memberikan hasil yang tertinggi terhadap pertambahan bobot badan dan konversi ransum ternak kelinci.

Kata kunci: jagung, sorgum, ransum, performans, kelinci local

\section{ABSTRACT}

EFFECT OF REPLACEMENT OF CORN WITH SORGUM Cv. KAWALI IN PELLET RANSUM ON LOCAL RABBIT PERFORM. The purpose of this study was to determine the effect of substitution corn with sorghum in rabbit rations on feed consumption, body weight gain, and ration conversion. The duration of the study was 28 days using 20 local rabbits. The statistical design used in this study was a completely randomized design, with 4 (four) treatment rations and 5 (five) replications. The four experimental rations, namely R0: $45 \%$ corn $+0 \%$ sorghum, R1: $30 \%$ corn $+15 \%$ sorghum, R2 $15 \%$ corn + $30 \%$ sorghum, R3 0\% corn $+45 \%$ sorghum. Variables were measured, viz: feed consumption, body weight gain and ration conversion. The results showed that the average of feed consumption, body weight gain, and feed conversion, were: 28.27-30.59 g /head /day, 15.76-21.55 g / head /day, and 1.42-1.80 g /head /day, respectively. Based on the analysis of variance, the treatments ration had no significant effect (P> 0.05) on consumption, but had a very significant effect $(\mathrm{P}<0.01)$ on body weight gain and feed conversion. The LSD test showed that 
all treatment rations using sorghum (R1, $\mathrm{R} 2$, and R3) gave results of body weight gain which were very significantly different ( $\mathrm{P}<0.01)$ and higher than R0. Whereas, on ration conversion, treatments $\mathrm{R} 1, \mathrm{R} 2$, and $\mathrm{R} 3$ give very different results $(\mathrm{P}<0.01)$ lower than R0. It is concluded that the substitution of corn with sorghum at the level of $45 \%$ in the ration gives the highest results for body weight gain and conversion of rations for rabbits.

Keywords: corn, sorghum, ration, performance, local rabbit

\section{PENDAHULUAN}

Kelinci merupakan salah satu ternak unggulan sebagai sumber protein hewani berkualitas baik. Keunggulan dari daging kelinci, yaitu memiliki kandungan rendah lemak dan kolestrol serta mengandung protein tinggi. Daging kelinci mempunyai serat yang halus dan berwarna sedikit pucat, sehingga daging kelinci dapat dikelompokan ke dalam golongan daging berwarna putih seperti halnya daging ayam.

Beberapa aspek yang menarik dari potensi produksi kelinci, antara lain kelinci merupakan sumber protein hewani yang bermutu tinggi. Kelinci dapat berkembang biak (8- 10 ekor/ kelahiran) dengan cepat karena dapat dikawinkan setiap waktu bila telah mencapai dewasa kelamin (umur 4 - 8 bulan), memiliki masa kebuntingan yang pendek, yaitu 30 hari (Onbasilar et al., 2007). Dari kulit kelinci dapat dibuat jas, mantel, peci atau kerajinan lain sedangkan kotorannya dapat digunakan sebagai pupuk kandang. Kelinci juga dapat dimanfaatkan sebagai hewan percobaan, hewan kesayangan dan sebagai alat peraga.

Berdasarkan tujuan pemeliharaan kelinci dapat dikelompokan menjadi 2 jenis, yaitu kelinci potong atau kelinci tipe pedaging dan kelinci hias. Kelinci pedaging adalah kelinci yang dibudidayakan untuk dikonsumsi dagingnya, sedangkan kelinci hias adalah jenis kelinci untuk hewan peliharaan yang lebih bersifat estetika (Setyawati, 2014). Khusus kelinci potong terjadi peningkatan permintaan diakibatkan karena terjadinya kenaikan harga daging sapi di pasaran sebesar $8,41 \%$. Pada tahun 2016, harga rata-rata daging sapi di tingkat konsumen paling tinggi terjadi di Kota Tanjung Selor yaitu sebesar Rp 141.501,00 per $\mathrm{kg}$ sedangkan harga paling rendah terjadi di Kota Denpasar yaitu sebesar Rp 85.999,00 per kg (Darman, 2011). Sementara itu, untuk kelinci hias juga mengalami perkembangan karena adanya hobi dari pemelihara kelinci jenis ini untuk tujuan hiburan dan estetika, sehingga menyebabkan permintaan kelinci jenis ini juga meningkat di pasaran.

Kelinci diklasifikasikan kedalam hindgut fermentor yaitu saluran pencernaan bagian belakang yang memegang peranan penting dalam pencernaan kelinci seperti sekum dan kolon (Irlbeck, 2001). Pakan kelinci pada dasarnya dapat dikelompokan 
menjadi dua yaitu hijauan dan konsentrat. Hijauan mengandung serat kasar yang relatif tinggi yakni $20-30 \%$, sedangkan konsentrat mengandung serat kasar yang lebih rendah dari hijauan yakni 5-7\% dan mengandung protein dan energi yang tinggi. Ransum merupakan komponen yang sangat penting dalam beternak kelinci potong atau kelinci hias, karena dari ransum inilah yang menjadi parameter penting untuk kelinci dalam menghasilkan performans yang baik (Hariadi et al., 1983) Untuk itu, diperlukan formula pakan yang mengandung nilai nutrisi yang seimbang dan bergizi agar dapat memenuhi kebutuhan kelinci.

Jagung adalah pakan yang memiliki kandungan serat kasar rendah dan diklasifikasikan sebagai pakan sumber energi, yang sangat dibutuhkan ternak baik untuk kebutuhan hidup pokok, produksi dan reproduksi. Kandungan karbohidrat dalam jagung dapat mencapai $80 \%$ dari keseluruhan bahan keringnya. Menurut NRC (1994), jagung merupakan bahan dasar penyusun ransum porsinya 50-60\%, memiliki kandungan protein 8,5\%; serat kasar 2,2\%; lemak 3,8\%; Ca 0,02\%; P 0,2\% dan Energi $3350 \mathrm{Kkal} / \mathrm{kg}$.

Jagung dalam ransum ternak kelinci sering menghadapi kendala dalam pengadaannya, dimana terjadi kelangkaan komoditas jagung dan bergejolaknya harga jagung di pasaran merupakan masalah yang dihadapi saat ini. Untuk itu perlu dilakukan upaya mencari pakan alternatif pengganti jagung.

Sorgum cv Kawali merupakan salah satu serealia yang dapat dijadikan sumber pakan cukup potensial untuk dikembangkan di Indonesia. Sorgum memiliki keunggulan tahan terhadap kekeringan dibandingkan jenis tanaman serealia lainnya, mampu beradaptasi pada daerah yang luas, produksi tinggi, serta tahan terhadap hama dan penyakit. Sorgum memiliki kandungan nutrisi yang tinggi. Berdasarkan analisis proksimat, sorgum mengandung: bahan kering $87 \%$; protein kasar 10,26\%; serat kasar 2,72\%; lemak 2,70\%; Ca 0,93\%; P 0,38\%; dan EM 3458 $\mathrm{Kkal} / \mathrm{kg}$ (Rumambi, 2013). Kandungan nutrisi sorgum yang hampir sama dengan jagung belum dimanfaatkan sebagai pakan sehingga memberi peluang untuk diteliti sebagai pakan alternatif pengganti jagung dalam ransum. Upaya pengantian jagung dengan sorgum akan memberikan nilai guna apabila diketahui akan memberikan performans yang baik pada ternak kelinci.

Berdasarkan uraian latar belakang diatas, maka telah dilakukan penelitian untuk mendapatkan data tentang pengaruh penggantian jagung dengan sorgum dalam ransum terhadap performans ternak kelinci lokal. 


\section{MATERI DAN METODE PENELITIAN}

Penelitian ini dilaksanakan dengan periode adaptasi selama 7 hari dan koleksi data adalah 28 hari. Penelitian ini menggunakan 20 ekor kelinci lokal fase pertumbuhan yang berumur $\pm 1,5$ bulan dengan bobot badan awal berkisar 153 $200 \mathrm{~g}$, diperoleh dari peternakan rakyat di Tumaratas Kecamatan Langowan. Kandang yang digunakan adalah 20 unit yang terbuat dari kayu, seng dan kawat berukuran $70 \mathrm{~cm}$ x $50 \mathrm{~cm}$ x $50 \mathrm{~cm}$. Tinggi kandang dari permukaan tanah $50 \mathrm{~cm}$ yang dilengkapi dengan tempat makan dan minum. Ransum percobaan terdiri atas campuran dari beberapa bahan seperti: sorgum, jagung, dedak halus, bungkil kelapa dan tepung ikan yang dibuat dalam bentuk pellet dengan wortel. Ransum yang diberikan sesuai dengan kebutuhan bahan kering berdasarkan fase pertumbuhan. Pemberian ransum dilakukan dua kali sehari pada pukul 09.00 - 10.00 Wita dan pukul 16.00 - 17.00 Wita yang disesuaikan dengan kebutuhan bahan kering ternak kelinci sesuai fase pemeliharaannya (g/ekor/hari).

Tabel 1. Kebutuhan nutrien kelinci masa pertumbuhan

\begin{tabular}{ll}
\hline Nutrien & \multicolumn{1}{c}{ Kebutuhan } \\
\hline Digestible Energy* & $2100-2500$ Kkal \\
Protein* & $16-18 \%$ \\
Lemak $* *$ & $2-4 \%$ \\
Serat Kasar* & $12-16 \%$ \\
\hline
\end{tabular}

$\begin{array}{ll}* & \text { NRC (Nutrien Requirements of Rabbits), } 1994 \\ * * & \text { Cheeke, } 1987\end{array}$

Tabel 2. Kebutuhan bahan kering kelinci berdasarkan periode pemeliharaanya

\begin{tabular}{llc}
\hline Periode Pemeliharaan & Bobot $(\mathrm{kg})$ & $\begin{array}{c}\text { Kebutuhan Bahan } \\
\text { Kering/gram/ekor/hari }\end{array}$ \\
\hline Muda & $1,8-3,2$ & $111-172$ \\
Dewasa & $2,3-6,8$ & $91-202$ \\
Bunting & $2,3-6,8$ & $112-248$ \\
Menyusui & 4,5 & 518 \\
\hline
\end{tabular}

Setyawati, R. 2014

Tabel 3. Komposisi zat- zat makanan bahan pakan penyusun ransum

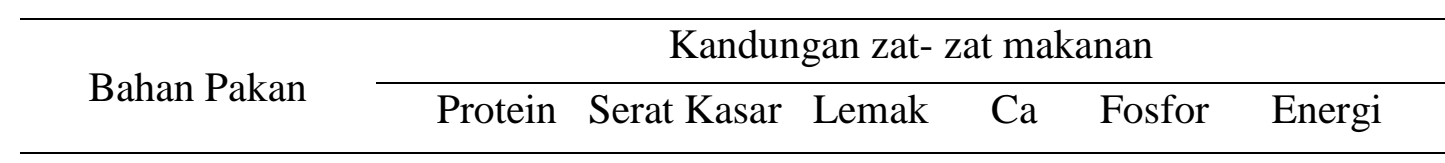




\begin{tabular}{llllccc}
\hline Wortel*** & 8,9 & 36,38 & 2,93 & 0,30 & 0,12 & 3070 \\
Tepung Sorgum** & 10,26 & 2,72 & 2,70 & 0,93 & 0,38 & 3510 \\
Tepung Jagung* & 8,5 & 2,2 & 3,8 & 0,02 & 0,2 & 3350 \\
Dedak halus* & 12,9 & 11,4 & 0.7 & 0,07 & 1,5 & 2980 \\
Bungkil kelapa* & 19,2 & 14,4 & 2,1 & 0,17 & 0,65 & 1525 \\
Tepung ikan* & 60,05 & 0,7 & 9,4 & 5,11 & 2,88 & 2820 \\
\hline
\end{tabular}

* NRC. 1994

** Rumambi, A. 2013

*** Sihaloho, S. 2018

Tabel 4. Komposisi kandungan bahan pakan serta kandungan zat- zat makanannya

\begin{tabular}{lcccc}
\hline \multirow{2}{*}{ Bahan pakan } & \multicolumn{4}{c}{ Perlakuan } \\
\cline { 2 - 5 } & \multicolumn{1}{c}{$\mathrm{R} 0$} & $\mathrm{R} 1$ & $\mathrm{R} 2$ & $\mathrm{R} 3$ \\
\hline Wortel & 30 & 30 & 30 & 30 \\
Tepung Sorgum & 0 & 15 & 30 & 45 \\
Tepung Jagung & 45 & 30 & 15 & 0 \\
Dedak halus & 3 & 3 & 3 & 3 \\
Bungkil kelapa & 3 & 3 & 3 & 3 \\
Tepung ikan & 19 & 19 & 19 & 19 \\
\hline Jumlah & 100 & 100 & 100 & 100 \\
\hline & & Kandungan zat- zat makanan & \\
\hline Protein \% & 16,49 & 16,75 & 17,02 & 17,28 \\
Energi (EM/ Kkal) & 3132 & 3148 & 3164 & 3180 \\
Lemak \% & 3,65 & 3,49 & 3,32 & 3,60 \\
Serat Kasar \% & 2,74 & 2,82 & 2,89 & 2,97 \\
Ca \% & 1,09 & 1,22 & 1,36 & 1,49 \\
P \% & 0,80 & 0,83 & 0,89 & 0,94 \\
\hline
\end{tabular}

Pada Tabel 1, dapat dilihat bahwa kebutuhan nutrien kelinci masa pertumbuhan, Tabel 2, kebutuhan bahan kering kelinci berdasarkan periode pemeliharaanya, Tabel 3, komposisi zatzat makanan bahan pakan penyusun ransum dan Tabel 4, komposisi kandungan bahan pakan serta kandungan zat- zat makanannya.
Penelitian ini menggunakan Rancangan Acak Lengkap (RAL) menurut Steel dan Torrie, (1991), yang terdiri atas 4 perlakuan dan 5 ulangan. Jika terjadi perbedaan antar perlakuan dilanjutkan dengan uji beda nyata terkecil (BNT).

Ransum Perlakuan adalah $\mathrm{R} 0=$ Wortel dan Konsentrat dengan $45 \%$ jagung tanpa sorgum, R1= Wortel dan Konsentrat dengan $15 \%$ sorgum $+30 \%$ jagung, R2= 
Wortel dan Konsentrat dengan $30 \%$ sorgum $+15 \%$ jagung R3= Wortel dan Konsentrat dengan $45 \%$ sorgum $+0 \%$ jagung. Pemberian air minum dilakukan secara adlibitum serta penempatan ternak dan perlakuan dilakukan secara acak.

\section{HASIL DAN PEMBAHASAN}

Hasil percobaan terhadap konsumsi, ransum, pertambahan bobot badan dan konversi ransum disajikan pada Tabel 5.

\section{Konsumsi}

Rataan konsumsi kelinci pada penelitian ini berkisar antara 28,27-30,59 gram/ekor/hari. Rataan konsumsi ransum tertinggi diperoleh pada perlakuan $\mathrm{R} 3$ yaitu penggantian $45 \%$ jagung dengan sorgum dan terendah pada perlakuan R0 yaitu ransum tanpa sorgum. Kisaran rataan konsumsi ransum penelitian ini lebih rendah dari rataan konsumsi yang dinyatakan oleh Wuysang et al. (2017) pada kelinci berumur 2 bulan yaitu berkisar 58,14- 60,35 gram/ekor/hari dan hasil penelitian Nugroho et al. (2012) yang melaporkan bahwa rataan konsumsi bahan kering kelinci berkisar antara 54,6-57,5 gram/ekor/hari.

Analisis keragaman menunjukkan bahwa ransum perlakuan memberi pengaruh yang tidak nyata $(\mathrm{P}>0,05)$ terhadap konsumsi ransum. Namun, data memperlihatkan, semakin tinggi level penggunaan sorgum dalam ransum, semakin tinggi pula jumlah konsumsi. Sorgum memiliki kandungan pati yang tinggi sehingga mempengaruhi sifat organoleptik, yaitu rasa dari sorgum dimana kandungan pati yang terdapat pada sorgum yaitu sebesar $82,5 \%$ terkonsentrasi pada endosperma, sedangkan pada bagian lembaga kadar lemak 18,9\% dan

Tabel 5. Rataan Konsumsi Ransum, Pertambahan Bobot Badan dan Konversi Ransum

\begin{tabular}{lcccc}
\hline Variabel & \multicolumn{4}{c}{ Perlakuan } \\
\cline { 2 - 5 } & $\mathrm{R} 0$ & $\mathrm{R} 2$ & $\mathrm{R} 3$ & $\mathrm{R} 4$ \\
\hline Konsumsi (g/ekor/hari) & 28,27 & 29,90 & 29,92 & 30,59 \\
\hline $\begin{array}{l}\text { Pertambahan berat badan } \\
\text { (g/ekor/hari) }\end{array}$ & $15,76 \mathrm{a}$ & $19,14 \mathrm{~b}$ & $20,22 \mathrm{bc}$ & $21,55 \mathrm{c}$ \\
\hline Konversi & $1,80 \mathrm{~b}$ & $1,58 \mathrm{a}$ & $1,48 \mathrm{a}$ & $1,42 \mathrm{a}$ \\
\hline Konay
\end{tabular}

Keterangan: Superskrip yang berbeda pada pada baris yang sama menunjukan berbeda sangat nyata $(\mathrm{P}<0,01)$. 
komponen mineral 19,36\% (Suarni dan Fimansyah, 2005). Mas'ud et al. (2015) menyatakan Kandungan energi dalam ransum berpengaruh pada konsumsi ternak. Qisthon (2012) menambahkan bahwa kelinci akan berhenti makan apabila energi yang dikonsumsi telah cukup untuk kebutuhan metabolisme. Konsumsi pakan juga merupakan faktor esensial untuk menentukan kebutuhan hidup pokok dan produksi karena dengan mengetahui tingkat konsumsi pakan dapat ditentukan kadar zat makanan dalam ransum untuk mengetahui hidup pokok dan produksi (Heryanto et al., 2016).

\section{Pertambahan Bobot Badan}

Rataan pertambahan bobot badan berkisar antara 15,76 - 21,55 gram/ekor/hari. Rataan pertambahan bobot badan tertinggi diperoleh pada perlakuan R3 yaitu penggantian $45 \%$ jagung dengan sorgum yaitu 21,55 gram/ekor/hari dan terendah pada perlakuan R0 yaitu 15,76 gram/ekor/hari yaitu ransum tanpa sorgum. Kisaran rataan pertambahan bobot badan dalam penelitian ini masih sesuai dengan pendapat Lukefahr dan Cheeke (1990) bahwa PBB kelinci di daerah tropis sekitar 10-20 gram/ekor/hari.

Analisis keragaman menunjukkan bahwa perlakuan berpengaruh sangat nyata $(\mathrm{P}<0,01)$ terhadap pertambahan bobot badan. Uji lanjut beda nyata terkecil (BNT), menunjukkan bahwa pertambahan bobot badan perlakuan R3 berbeda sangat nyata $(\mathrm{P}<0,01)$ lebih tinggi dibandingkan dengan perlakuan R0, dan R1, namun tidak berbeda dengan perlakuan R2. Demikian pula perlakuan R2 dan R1 berbeda sangat nyata $(\mathrm{P}<0,01)$ lebih tinggi dari perlakuan R0, namun antara perlakuan R1 dan R2 tidak terdapat perbedaan $(\mathrm{P}>0,05)$. Angka pertambahan bobot badan dalam penelitian ini lebih tinggi dibandingkan dengan penelitian yang dilaporkan Polii et al. (2015), yaitu berkisar antara 11,73- 16,74 gram/ ekor/ hari.

Mas'ud et al. (2015), menyatakan pertambahan bobot badan ternak berbanding lurus dengan tingkat konsumsi pakannya. Hal ini berarti bahwa konsumsi pakan akan memberikan gambaran nutrien yang diperoleh pada ternak, sehingga memengaruhi pertambahan bobot tubuh ternak. Hal ini juga sesuai dengan yang dinyatakan Wuysang et al. (2017) Pertumbuhan yang optimal dipengaruhi oleh kualitas dan kuantitas pakan yang dikonsumsi.

\section{Konversi}

Rataan angka konversi ransum kelinci, berkisar antara 1,42 - 1,80. Rataan konversi pakan terrendah diperoleh pada perlakuan R3 yaitu ransum yang mengandung $45 \%$ jagung tanpa sorgum. 
Analisis keragaman menunjukkan bahwa perlakuan berpengaruh sangat nyata $(\mathrm{P}<0,01)$ terhadap konversi ransum. Rataan konversi ransum dalam penelitian ini lebih rendah dari penelitian Wuisang et al. (2017), yang menggunakan molasses dalam ransum kelinci yaitu 2,86-3,04. Secara praktis dari sudut pandang ekonomis, konversi pakan merupakan parameter yang paling banyak digunakan untuk mengestimasi efisiensi penggunaan pakan. Konversi ransum merupakan rasio dari jumlah ransum yang dikonsumsi dibagi bobot badan ternak kelinci (Maertens, 2009). Angka konversi ransum berbanding terbalik dengan nilai efisiensi ransum. Semakin rendah angka konversi ransum maka semakin tinggi angka efisiensi ransum, sehingga akan berpengaruh pada biaya ransum (Moningkey, 2016). Uji BNT menunjukkan, bahwa konversi ransum pada perlakuan R0 berbeda sangat nyata $(\mathrm{P}<0,01)$ lebih tinggi dibandingkan perlakuan R1, R2 dan R3, namun antara perlakuan R1, R2 dan R3 berbeda tidak nyata $(\mathrm{P}>0,05)$.

\section{KESIMPULAN}

\footnotetext{
Berdasarkan hasil pembahasan dapat disimpulkan bahwa penggantian jagung dengan sorgum $45 \%$ dalam ransum dapat memberikan hasil yang tertinggi terhadap pertambahan bobot badan dan
}

konversi ransum ternak kelinci. Dengan demikian dapat direkomendasikan, bahwa sorgum dapat digunakan sebagai pakan pengganti sebagian jagung dalam ransum ternak kelinci lokal.

\section{DAFTAR PUSTAKA}

Cheeke, P.R. 1987. Rabbit production. The Interstate Printers and Publishers Inc. Illinois.

Darman, 2011. Analisis ekonomi usaha ternak kelinci. Jurnal Binus Bussines Review. Vol. 2: p. 914 $-922$

Hariadi, B., Katiarso dan R. Herman. 1983. Pengaruh kadar protein ransum terhadap performans kelinci lokal. Media Peternakan. Vol. 8 (4) :1-9.

Heryanto. K. Maaruf, S.S. Malalantang, M.R. Waani. 2016. Pengaruh Pemberian Rumput Raja (Pennisetum Purpupoides) Dan Tebon Jagung Terhadap Performans Sapi Peranakan Ongole (Po) Betina. Jurnal Zootek 36 (1): 123-130.

Irlbeck, H. A. 2001. How to feed the feed the rabbit (Orytogalus cuniculus) gastrointestinal tract. J. Anim. Sci. 79: 343-346.

Lukefahr, S.D dan P.R. Cheeke. 1990. Rabbit project planning strategist for developeing countries. J. Livestock Research For Rural Development Vol: 2 p. 2.

Maertens, L. 2009. Possibilities to reduce the feed conversion in rabbit production. Giornate di 
Coniglicoltura. Journal ASIC. p. 110.

Mas'ud, C. S., Y.L.R. tulung, J. Umboh, C.A. Rahasia. 2015. Pengaruh pemberian beberapa jenis hijauan terhadap performans ternak kelinci. Jurnal Zootek Vol. 35(2): 289-94.

Moningkey, S. 2016. Potensi Isi Potensi Isi Rumen dan Sludge Sebagai Bahan Pakan Lengkap Terhadap Penampilan Produksi Kelinci Lepas Sapih. Disertasi. Program Pascasarjana.Universitas Brawijaya, Malang.

NRC.1994. Nutrien Requirements of Rabbits. Rev Ed. National Academy Press. Wasington DC.

Nugroho, S. S., P. S. B. Subur, dan Panjono. 2012. Pengaruh pengunaan konsentrat dalam bentuk pelet dan mash pada pakan dasar rumput lapangan terhadap palatabilitas dan kinerja produksi kelinci jantan. Buletin Peternakan Vol. 36 (3): 169-173.

Onbasilar, E. E and I Onbasilar. 2007. Effect of cage density and sex food utilization and some stress parameter of young rabbit. Trop. Anim. Sci. 34 p. 3

Polii, P.Y., K. Maaruf, Y. Kowel, H. Liwe. Y. Rahardjo. 2015. Pengaruh penambahan zat aditif (Enzim dan Asam Organik) dengan protein tinggi dan rendah pada pakan berbasis dedak terhadap performan kelinci. Jurnal Zootek Vol. 35 (2): 280-288.
Qisthon, A. 2012. Pengaruh imbangan hijauan-konsentrat dan waktu pemberian ransum terhadap produktivitas kelinci lokal jantan. Jurnal Penelitian Pertanian Terapan Vol. 12 (2): 69-74

Rumambi, A. 2013. Karakteristik pertumbuhan sorgum dengan pemupukan urea berbeda sebagai sumber nitrogen. Laporan Penelitian. Unggulan Perguruan Tinggi (BPOTN) Universitas Sam Ratulangi, Manado.

Setyawati, R. 2014. Panduan Lengkap Dan Bisnis Kelinci Potong Dan Hias. Flash Books. Jakarta.

Sihaloho, S. 2018. Modifikasi Pakan Menggunakan Tepung Wortel Untuk Meningkatkan Pertumbuhan Dan Kecerahan Warna Ikan Koi. Skripsi. Program Studi Kimia. Universitas Sumatera Utara, Medan.

Suarni dan I.U. Firmansyah. 2005. Potensi Sorgum Varietas Unggul Sebagai Bahan Pangan Untuk Menunjang Agroindustri. Prosiding Lokakarya Nasional BPTP Lampung, Universitas Lampung. p. 541-546.

Stell, R. G. D. and J. H. Torrie. 1991. Principle And Procedure Statistics. Me Graw Hill Book Company.

Wuysang, S., C.A. Rahasia, J. Umboh, Y.L.R. Tulung. 2017. Pengaruh penggunaan molases sebagai sumber energi pakan penguat dalam ransum terhadap pertumbuhan ternak kelinci. Jurnal Zootek Vol. 37 (1): $149-155$. 